\title{
Indonesian and Malaysian Press Policy: Pre and Post-Independence
}

\author{
Dafrizal Samsudin \\ dafrizal@comm.uir.ac.id \\ Fakultas Ilmu Komunikasi, Universitas Islam Riau, Indonesia \\ Faridah Ibrahim \\ faridah@iukl.edu.my \\ Infrastructure University of Kuala Lumpur, Malaysia
}

\begin{abstract}
Indonesia and Malaysia are the two countries that come from a family of the Malay Archipelago. These two countries were born after a different colonial occupation namely the Netherlands and the United Kingdom. However, each country has a different press system and policy. This study aims to look at the main objectives of Indonesian and Malaysian press policy through critical reviews of secondary data obtained from library research based on categories in two stages of newspaper development in pre and post-independence. This study found that, in Indonesia, in the pre-independence era, the main objectives of Indonesian press policy were to control security and public order, and abuse of the press, during the Japanese occupation as Preventive censorship, and Propaganda. In the Post-Independence, the main objectives policy of the press namely as Freedom of the Press, support 'political manifesto' and Implementing the "Pancasila Press System". Meanwhile, in Malaysia, in the preindependence era, the main objective of the policy press was as a controlling factor to act as a medium of internal racial conflict among the Chinese in Singapore and Kuala Lumpur due to differences of support for the Chinese monarchy since 1911, and propaganda machinery. In Post-Independence, the main objective of the press is to control and maintain the political stability of the country and prevent racial riots due to political and economic crisis. This study concludes that the main objectives of the Indonesian and Malaysian Press Policy are made in accordance with the direction of the system and political policies of the ruling regime.
\end{abstract}

Keywords: Indonesian Press; Malaysian Press; Press Policy; Colonial Era; pre and postIndependence

\section{INTRODUCTION}

Indonesia and Malaysia are not only two neighboring countries, but also the two main countries in the Malay world. The two countries are also historically and culturally bound. Therefore, the two countries are known by the nickname "Kins State" (Liow, 2004). However, historically, Indonesia and Malaysia had experienced colonial occupation by Europeans such as the Portuguese, Dutch and British. One of the goals of European arrivals to Indonesia and Malaysia was to get a sources of spices such as cloves, pepper, nutmeg and mace (Ricklefs, 2008). At the same time, Indonesia and Malaysia were also occupied by 
Japan during 1941-1945. However, Japan's defeat in the Greater East Asia war against the Allies in 1945 ended the Japanese occupation of Southeast Asian countries (Ishak, 2012; Ho, 2009; Ricklefs, 2008). Then, Indonesia declared independence on August 17, 1945 from Dutch colonialism (Ricklefs, 2008), while Malaysia declared officially its independence on 31 August 1957 from British colonial rule (Andaya \& Andaya, 2016).

Related to this, the press activity is something that is not separate from the existence of a state. In the sense of the word, the activities of the press in Indonesia and Malaysia have started since the colonial era. For example, the first newspaper in Indonesia during the colonial period was the Bataviasche Nouvelles en Politique Raisonnementen on 20 June 1774 during the Dutch colonial era (Anom, 2013). Meanwhile in Malaysia, the first newspaper was The Government Gazette during the British colonial era (Hasim, 2005). Therefore, when viewed from the history, then either the Indonesian and Malaysian media have experienced a media policy landscape separately according to the media system adopted by the two countries (Kakiailatu. 2007; Nain \& Wang, 2000).

In the meantime, each country has its own press system and laws, this is because each country has different goals, media functions as well as different socio-political backgrounds and national policies (Anom, 2009). For example, Hasim (2005) points out that in Indonesia the term press is used refer to press freedom, compared to Malaysia which uses the term "akhbar". However, the term freedom of 'akhbar' has been used as a match for the term "freedom of press". Therefore, historically, it can be assumed that the influence of the historical experiences of Indonesia and Malaysia as countries that were respectively long colonized by the Dutch and British had an impact on differences in the press system and policies that followed the political policy system.

Meanwhile, there are several issues of comparative study of the Indonesian and Malaysian press, for example; Mauliansyah (2018) sees the issue of press freedom as a source of press conflict for Indonesia and Malaysia as neighboring countries, Anom (2009) sees the issue of press freedom in Malaysia and Indonesia. Steele (2011, 2013), looks at aspects of journalistic values, Islam and ethics in Malaysia and Indonesia. In this regard, this study aims to see how the press policy objectives constructed by the the Indonesian and Malaysian government administration during pre and post-Independece?

\section{METHODOLOGY}

The principle of the present research is literature review by using historical comparative approach based on library research. Most of the data obtained were from the collection of some text books, journal articles, and book chapters. Technically, the data analyzed based on descriptive qualitative methodology. Moleong (2010) quoting Bogdan and Taylor's statement said that one of the research procedures are to seek descriptive data written by the people. Furthermore, the data is described and interpreted by taking into account the historical experience momentum events based on the categories of Indonesian and Malaysian press policies before and after independence. In this regard, the focus of the analysis of this research is to see the pattern of press policy objectives of the Indonesian and Malaysian governments based on regulatory products that are applied to every moment of crucial historical events in the scope before and after independence. 


\section{INDONESIAN PRESS POLICY}

\section{Experiences in Pre-independence Era}

In Indonesia, the history of the first newspaper was recorded during the Dutch colonial era under the rule of General Governor Gustaaf Willem Baron van Imhoff. Among the first newspapers published were the Batavaiasche Nouvelles on 7 August 1744 run by JE Jordens, and the weekly Het Vendu-Nieuws 1776 -1809 published by L. Dominggus, all of which were oriented as commercial channels of the Verenigde Nederlandsche Geoctroyeerde Oost-Indische Compagnie (VOC) during the reign of General Herman Willem Daendels 1809 (Surjomihardjo, 2002; Adam, 1995). In addition, the Bataviasche Koloniale Courant in 1810 also oriented to commercial advertising, ceased in 1811 as Batavia fell into British hands, the Java Government Gazette in 1812, and when the Dutch returned to power, it was replaced by the establishment of the Bataviasche Courant newspaper in 1816, twelve years later this newspaper was replaced by the Javasche Courant newspaper (Adam, 1995; Atmadi 1982).

The first Indonesian publication was the weekly "Medan Periyayi" in 1907 (Arifin, 1988). Due to the sense of nationalism, the newspaper that loudly criticized the Dutch administration has become $a$ 'press of political struggle' (Hill, 2000). Many newspapers were established by figures of the Indonesian struggle movement, among others; Suluh keadilan, led by Djoko Damono, Fikiran Rakyat, led by Bung Karno, Pendidikan Nasional, led by Bung Hatta, Panji Masyarakat, led by HAMKA, Utusan Hindia led by HOS. Cokro Aminoto (Anuar Arifin 1988). In terms of journalism practice during the Dutch occupation, newspapers were regulated under the Press Act 1856, which was preventive, then replaced by the Press Act 1906, which oppressed, further on 7 September 1931 by order of Persbreidel Ordonatie 1931 (Surjomihardjo, 2002; Adam, 1995; Marters, 2003). For the Netherlands, press control was aimed at controlling public safety and public order and misusing the press (Surjomihardjo, 2002; Marters, 2003).

In March 1942, the Dutch East Indies (Indonesia) was captured by the Japanese army. Japan introduced Law No. 16/1942 to regulate publishing and communication, and all antiJapanese newspapers such as Dutch, Indonesian, and Chinese newspapers were banned from publication, and preventive censorship measures were enacted (Surjomihardjo, 2002). Then, during the Japanese occupation of 1942-1945, all Dutch-language newspapers were discontinued, and Japanese government published The Dai Nippon in Japanese with the motto "Dai Too-A Sensoo" (the rise of greater Asia), and contained Japanese propaganda (Toeti Kakiailatu, 2007: 62), and the press was controlled by the Japanese army (Kusuma 1981).

\section{Experiences in Post-independence Era}

After the Independence of Indonesia was declared on 17 August 1945, the era was interpreted as the independence of Indonesian human rights to freely determine their own destiny guaranteed by the Constitution of the Republic of Indonesia 1945 (Arifin, 1988). In addition, under Sukarno's rule, Indonesian newspapers also enjoyed a period of press freedom guaranteed in the Provisional Constitution of the Republic of Indonesia 1950 (Surjomihardjo, 2002; Marters 2003; Idris \& Gunaratne 2000), this was also in line with the practice of 'liberal democracy' in 1945-1959, and the trend was a newspaper closely associated with political parties (Idris \& Gunaratne 2000). 
However, in 1957, when there was political instability, economic downturn, and the rise of insurgency outside Java, freedom of the press ceased again (Marters 2003). After two years later, this situation led to the declaration of the 1959 Presidential Decree, one of which contained a return to the 1945 Constitution and the repeal of the 1950 Provisional Constitution, as a result of which the press was no longer independent, and complied with the 'Guided Democracy' policy of Sukarno's government, and supported the Pancasila ideology as a form of 'political manifesto' (Kusuma 1971; Kakiailatu 2007). The publication of newspapers is subject to Publication Permit (SIT) provided it complies with the Commanderin-Chief Regulation (Peperti) 10/1960 on a newspaper publishing license consisting of 19 clauses, and Penpres No. 6/1963. (Surjomihardjo, 2002).

Meanwhile, after the failed political coup on 30 September 1965 backed by the Indonesian Communist Party (PKI), there was a "transfer of power" from President Sukarno to Lieutenant General Suharto through Surpersemar (Surat Perintah Sebelas Maret 1966 ('Letter of Command, 11 March 1966')) taking over the unstable state (Kakiailatu, 2007). At the beginning of Suharto's rule in 1963-1967, about 163 newspapers in the country were canceled, thousands of communist media workers or those accused of communism were arrested and killed (Kakiailatu 2007: 63). Among the newspapers that survived at that time were Merdeka (1945), Jawa Pos, Surabaya (1949), Suara Merdeka, Semarang (1950), Fikiran Rakyat, Bandung (1956), Sinar Harapan, Parkindo, Protestan Party (1961), and Kompas, Roman Catholic (1965) (Idris \& Gunaratne 2000: 208). In 1968 Soeharto was officially appointed as Sukarno's successor President and as the beginning of the "new order" by implementing the "Pancasila Press System" (Anom 2008). Under Suharto's rules, the Publishing Permit (SIT) and Printing Permits (SIC) are still in force, and the press is regulated based on Press Law No.11 / 1966, then continued under Press Law No. 4/19667, and that was also reaffirmed by the Regulation of the Minister of Information of the Republic of Indonesia No. 03 / PERMENPEN / 1969 (Anom, 2008; Kakiailatu, 2007).

In the early 1970s, there were student demonstrations against Suharto's economic policies and his failure to carry out his egalitarian promises, leading to the riots of January 15 , 1974 (MALARI) (Kakiailatu, 2007). In the scholars' views, the Malari incident led to the cancellation of newspaper publications and the arrest of journalists who loudly criticized Suharto's government policies (Anom, 2008; Kakiailatu, 2007; Hill 2000). The newspaper suspension incidents that criticized the Suharto police include Nusantara, Suluh Berita, Mingguan Mahasiswa Indonesia, Kami, Indonesia Raya, Abadi, The Jakarta Times, Mingguan Wenang, Pemuda Indonesia, Express, Pedoman, dan Indonesia Pos (Surjomihardjo, 2002; Kusuma, 1981). Subsequently, in 1978, the suspension of Kompas, Sinar Harapan, Merdeka, Pelita, The Indonesia Times, Sinar Pagi and Pos Sore due to criticism and opposition of students and the people to the corrupt practices of Suharto's government (Kusuma 1981; Anom 2008). Besides, in the 1980s there were several newspapers established among others; The Jakarta Post (1983), Bisnis Indonesia (1985), The Military Newspapers_ Jayakarta (1985) and Surya (1986), and Republika, pro-Muslim rule were established in 1983 (Idris \& Gunaratne 2000). However, Suharto's government reformed the policy of controlling the press by changing Law No. 4 of 1967 to Law No. 21 of 1982 under the "Press Pancasila" policy. Subsequently, the government replaced the Publication Permit (SIT) with Press Publishing Business License (SIUPP) (Sudibyo, 1999; Anom, 2008). In addition, every journalist and newspaper must be under the auspices of an organization recognized and managed by the government, namely the Indonesian Journalists Association (PWI) and the Newspaper Publishers Union (SPS) (Sen \& Hill, 2007). In short, under Suharto's rule it was found that the press was handled in several stages namely; first through self-censorship by journalists and authors. Second, control through persuasion and 
warning. Third, through the action of revocation refers to SIUPP and other licenses. The government ensures that the Indonesian press should be 'Pers Pancasila' i.e. must be 'responsible', obey the law, follow instructions, and abide by the ideology and interests of the rulers (Kakiailatu, 2007: 65).

Control after control imposed on the world of Indonesian journalism under the new era of Suharto, did not dampen the desire of journalists to fight for freedom of the press in Indonesia. The establishment of the Alliance of Independent Journalists (AJI) is a response to PWI as the only journalism organization recognized by the Suharto government. AJI rejects all forms of interference, intimidation, censorship and media restrictions that deny freedom of speech, and openness of information, freedom of association is a human right (Sen \& Hill, 2007). Due to the political turmoil in 1998, until the demonstration of thousands of students, workers, and other components of society occupied the parliament building demanding Suharto's resignation, reform, and democratization and finally forced Suharto to step down and Deputy President BJ Habibie took over as President. Under the administration of President BJ Habibie, the freedom of the press is getting stronger as enshrined in Press Law No. 40/1999 replaces Press Law Number 21 of 1982, through minister of information, General Yunus Yospiah, the censorship of the press ended and SIUPP abolished, anyone could form a new mass media, and Journalists were given the freedom to choose a shelter organization, abolished PWI as the only representative of journalistic organizations and recognized existence AJI (Kakiailatu, 2007; Sen \& Hill, 2007; Samsudin \& Nasution, 2021). In addition, still in the reform era, the law that regulates media policy in Indonesia is divided into two rules, namely Law Number 40 of 1999 which regulates the press, while Law Number 32 of 2002 concerning broadcasting regulates procedures for broadcasting, broadcast content, and broadcasting infrastructure (Anom, 2015; Rachmiatie, et al 2020).

Finally, from the whole narrative discussion above, it can be described the trend of Indonesian government system, Press Law, regulation and policy as in the table below:

Table 1. Indonesian Government Administration and Press Policy

\begin{tabular}{|c|c|c|}
\hline $\begin{array}{c}\text { Government } \\
\text { Administration }\end{array}$ & Press Law and Regulation & Main Objectives Policy \\
\hline \multicolumn{3}{|c|}{ Indonesian Press in the Pre-Independence Era } \\
\hline Dutch colonial & $\begin{array}{l}\text { - } \quad \text { Press Act } 1856, \\
\text { - } \quad \text { Press Act } 1906, \\
\text { - } \quad \text { Persbreidel Ordonatie } 1931 \\
\end{array}$ & $\begin{array}{l}\text { Control security and public } \\
\text { order and abuse of the press }\end{array}$ \\
\hline $\begin{array}{l}\text { Japanese } \\
\text { Occupation }\end{array}$ & - Law No. 16/1942 & $\begin{array}{l}\text { Preventive censorship, } \\
\text { Propaganda }\end{array}$ \\
\hline \multicolumn{3}{|c|}{ Indonesian Press in the Post-Independence Era } \\
\hline $\begin{array}{l}\text { Sukarno 'liberal } \\
\text { democracy' 1945- } \\
1959\end{array}$ & $\begin{array}{l}\text { Provisional Constitution of the } \\
\text { Republic of Indonesia } 1950\end{array}$ & Freedom of the Press \\
\hline $\begin{array}{l}\text { Sukarno 'Guided } \\
\text { Democracy' }\end{array}$ & $\begin{array}{ll}\text { - } & \text { Commander-in-Chief } \\
& \text { Regulation (Peperti) 10/1960 } \\
\text { - } & \text { Penpres No. 6/1963 }\end{array}$ & $\begin{array}{l}\text { Comply and support 'political } \\
\text { manifesto' }\end{array}$ \\
\hline $\begin{array}{l}\text { Under Suharto's } \\
\text { rules of the new }\end{array}$ & $\begin{array}{l}\text { - } \quad \text { Press Law No.11 / 1966, } \\
\text { - } \quad \text { Press Law No. 4/19667, }\end{array}$ & $\begin{array}{l}\text { Implementing the "Pancasila } \\
\text { Press System" }\end{array}$ \\
\hline
\end{tabular}




\begin{tabular}{|l|l|l|}
\hline order policy & $\begin{array}{l}\text { Regulation of the Minister of } \\
\text { Information of the Republic of } \\
\text { Indonesia No. 03 / }\end{array}$ & \\
& $\begin{array}{l}\text { PERMENPEN / 1969 } \\
\text { Press Law No. 21 of 1982 }\end{array}$ & \\
\hline $\begin{array}{l}\text { Under the } \\
\text { administration of } \\
\begin{array}{l}\text { BJ Habibie- } \\
\text { "reformation era" }\end{array}\end{array}$ & $\bullet \quad$ Press Law No. 40/1999 & The freedom of the press \\
\hline
\end{tabular}

\section{MALAYSIAN PRESS POLICY}

\section{Experiences in Pre-independence Era}

In Malaysia, there are several important phases that tend to be debated by scholars in the press namely the British colonial phase, independence, and under the rule of Dr Mahathir (Hasim, 2004); Nain \& Wang, 2000; Anuar, 2001). The establishment of the press dates back to the time of the British colonial occupation. The Government Gazette, the original name of The Prince of Wales Island Gazette was established on 28 February 1806 in Penang by a newspaper operator from Madras, A.B. Bone (Hasim, 2004). Meanwhile, the press in Malay (Jawi) appeared in 1876, in the Chinese press in 1880, and the press in Tamil Nesan 1875. Only The New Straits Times published in 1845 exists to this day (Badarudin, 2002: 10).

In connection with the first publication of The Government Gazette on March 1, 1806, Bone agreed to send proof documents to the government for review before publication (Safar 2004). Indeed, the press in Malaysia was controlled initially by the British East India Company (SHTB), then by the British government, and finally by the Government of Malaysia. Freedom of the press can be created when calculated from the first publication of The Government Gazette which was only 85 years old from the period 1835 to 1920. Press freedom ended when the Ordinance Presses 1920 enforced in Straits Settlements in 1920, and the same law enforced in the Federated Malay States in 1924 namely Printing Press Enactment 1924. Ordinance Presses was created at the urging of Chinese advisers due to clashes between them in Singapore and Kuala Lumpur due to differences in attitudes towards the rebellion against the Chinese Emperor since 1911 (Hasim, 2005).

Furthermore, in 1939, the Straits Settlements, Malaya was preoccupied with Japanese propaganda. Japan's role in strengthening the propaganda by publishing newspapers such as Japanese, Chinese, and English, as well as buying Malay newspapers. This situation prompted the Governor of the Straits Settlements to enact legislation to control the press with the aim of fighting Japanese propaganda in Singapore. In addition, the bill was passed by the Legislative Assembly on 16 October 1939. There are two important points in the ordinance amended in section 6A namely the permit required to publish the newspaper, and the Colonial Business Secretary may direct the newspaper to be printed in the language specified in the permit. More specifically, the law in 1939 allowed the press to be controlled directly (Hasim, 2004, 2005).

Following the outbreak of the Second World War, and Japan already defeated the British on February 15, 1942, until Malaya and Singapore under the reign of the Japanese army. This situation further strengthened the position of the press as the main machinery of the Japanese Propaganda Department, and the press was also operated and supervised by the 
Japanese military administration (Safar, 2004). However, in the 1945s and 1957s, among the established newspapers were China Press (1946), Berita Harian (1957), the first Malay newspaper in Latin script after World War II, prepared for the independence of Malaysia; and four Sarawak newspapers-Sarawak Tribune (1945), with major English-language national newspapers, Chinese Daily News (1945) in Kuching, Miri Daily News (1945); and See Hua Daily News (1952) in Sibu. Some Malay-language newspapers like Suara Rakyat (1945) in Ipoh, Pelita Rakyat (1946), and Warta Negara (1945), in Kuala Lumpur (Badarudin, 2002). The structure of the print media industry and the policies and regulations that continue to affect the press, had developed after the war during a period marked by particularly dramatic events. These included the Emergency (1948-60), when Malaya faced a serious communist threat. Various laws of continuing importance as mentioned earlier were passed during this time to control publications and subversive acts (Ibrahim 2004: 133).

\section{Experiences in Post-independence Era}

Malaya achieved independence on August 31, 1957 and formally established in 1963, Malaysia comprised of Malaya, Singapore, Sarawak and Sabah. On its way, Singapore became an independent country in 1965. However, in the early days of independence Malaya, an incident dispute between UMNO and Utusan Melayu. UMNO has tried to take over Utusan Melayu in order to be more favored by the press, the contents of Utusan Melayu did not want to be controlled by political forces and want the freedom of the press and democracy in Malaya. However, in 1961 UMNO managed to control the newspaper through the purchase of shares by individuals close to the government, until the majority shares fell into the hands of UMNO (Hasim, 2004, 2005). Among the newspapers established after Malaysia became independent are; Utusan Malaysia (1967) and the weekly edition known as Mingguan Malaysia (1964), The Star (1971) in Penang, Then The New Straits Times as the largest local English-language daily. In addition, there are political party newspapers among others; Rocket under the Democratic Action Party (DAP), Harakah under the Malaysian Islamic Party (PAS), with limited publishing permission among party members, but its distribution is free as an alternative newspaper (Hasim et al. 2000).

The incident of racial unrest on 13 May 1969 was due to the fact that after the election the ruling party of the Alliance failed to reach two-thirds of the parliamentary seats, while the opposition gained the unexpected victory (Nain \& Wang 2000). Following the events of 13, May 1969 had an impact on the newspaper suspension for more than two days starting on 16 May 1969 (Hasim, 2004). The opposition accused by the Alliance using freedom of expression to exploit racism and dissatisfaction among non-Malay ethnic Chinese and Indians (Sani, 2004). In this regard, Information Minister Hamzah said that the government will impose censorship before newspapers are allowed to be published so that the news does not raise racist feelings. Hamzah also reminded that newspapers that refuse to accept censorship will continue to be suspended (Hasim, 2004). However, the matter has been opposed by the editor-in-chief of The Straits Times group, L.C. Hoffman, who expressed opposition to the suspension of newspaper publications (Hasim, 2004; Anuar, 2001; Nain \& Wang, 2000). Among the climaxes after the events of 13, May 1969 was the UMNO General Assembly on 23 June 1972 unanimously agreed that local newspapers should be owned by local residents as well as their staff (Hasim, 2004). So, The Strait Times newspaper group which was previously a shareholder was Singaporean, then bought $80 \%$ by Pernas, a national corporate company, then transferred to UMNO through Flee Holdings, and in 1984 the transfer of full ownership when Straits Times, Singapore relinquished the remaining $20 \%$ of the company's 
shares, then followed by the change of company name to The New Straits Times (Anuar, 2001; Nain \& Wang 2000).

The political crisis and financial scandal that took place in 1987 are among the most important moments in the history of press freedom in Malaysia. UMNO's internal political battle involving Mahathir's group known as 'team A' and Tengku Razaleigh Hamzah's group known as 'team B' had an impact on UMNO when it was declared an illegal party by the Kuala Lumpur High Court in 1987. At the same time, the issue of Chinese education and financial scandals involving Chinese depositors has triggered inter-racial conflicts that have arisen between UMNO and Chinese Political Party (MCA) and Democratic Action Party DAP which have pressured the government to investigate financial scandals (Nain \& Wang 2000).

The culmination of this event was the birth of the Weeding Operation (Operasi Lalang) which has sacrificed more than 100 victims including opposition politicians, social activists, academics, religious members, and human rights activists detained under the ISA (Anuar, 2001). In addition, there are three mainstream national media, The Star, Watan, and Sin Chew Jit Poh whose publication permits have been suspended. The event also affected the repeal of the Printing Presses and Publishing Act 1984 in 1988 (Nain \& Wang 2000). The repeal of the act is considered to further strengthen the government's control over the media, as all newspaper publications in Malaysia must obtain a print permit and be approved by the Home Ministry before it is published and subsequently renewed once a year (Anuar 2001; Nain \& Wang 2000 ).

Furthermore, the 1998 political crisis in which the then Prime Minister Mahathir Mohammad fired Anwar Ibrahim from his position as Deputy Prime Minister on 2 September 1998. The matter is said to be due to differences of opinion between Mahathir Mohammad and Anwar Ibrahim in the resolution of the economic crisis that hit Asia. For Anwar Ibrahim to overcome the economic crisis proposed help from the IMF, but this offer was opposed by Mahathir. Anwar is also accused of abusing power among certain ministries, especially in UMNO. According to Anwar Ibrahim, the matter was considered a high-level conspiracy in an attempt to 'kill' him politically (Anuar, 2001). This situation invites sympathy among supporters of Anwar Ibrahim. In addition, it is influenced by the ongoing reform situation in Indonesia where President Soharto was then bombarded by criticisms such as Corruption, Nepotism, and Chronism (Nain \& Wang, 2000). This incident had an impact on the mass media when Utusan Malaysia Editor-in-Chief Johan Jaafar resigned and Ahmad Nazri Abdullah was transferred from Berita Harian Editor-in-Chief to a Company under UMNO, Malaysian Resources Berhad, and TV3 Director of Operations Yunus Said also resigned, then replaced by a close person to Mahathir (Sani, 2004; Anuar, 2001). At the same time, two weekly tabloids, Warta KL (KL News) and Eksklusif (Exclusive) achieved success in early 1999, which contained political news, especially regarding the removal of Anwar Ibrahim from the Deputy Prime Minister and news about Parti Keadilan Rakyat led by Anwar's wife, Wan Azizah Ismail (Hasim, et al. 2000).

Basically, in Malaysia, the press is governed by rules and regulations, the executive is in control of the press through rules and regulations (Hasim, 2004). Thus, the mass media in Malaysia reflects the state of government and the society in which it operates (Ibrahim, 2003: 57), as it is controlled by the government and media companies allied with government leaders for the survival of political life from the ruling party and strengthen the power of leaders (Sani, 2004). Like the statement of Nain and Wang that the centralization of media ownership affiliated with the hands of political power has been a norm in Malaysia for a long time (Nain \& Wang 2000: 266). In Short, there are several laws that control the freedom of the press in Malaysia namely the Printing Press Act 1948, Official Secrets Act 1972, Sedition 
Act 1948, Defamation Act 1957, and Internal Security Act 1960 (Hasim, 2005; Sani, 2004). Answering critics of its purported stranglehold on the press, the government has argued that a 'guided' press is important for national security and nation building against a backdrop of multi-ethnic society in Malaysia (Ibrahim 2004: 133)

Finally, referring to the whole narrative discussion above, it can be summarized the trend of Malaysian government system and press law, regulation and policy in the table below:

Table 2: Malaysian Government Administration and Press Policy

\begin{tabular}{|c|c|c|}
\hline $\begin{array}{c}\text { Government } \\
\text { Administration }\end{array}$ & Press Law and Regulation & Main Objectives \\
\hline \multicolumn{3}{|c|}{ Malaysian Press in the Pre-Independence Era } \\
\hline $\begin{array}{ll}\text { - } & \text { British East India } \\
\text { Company (SHTB) } \\
\text { - } & \text { British Colonial } \\
\text { - } & \text { The Strait Settlements } \\
\text { - } & \text { Federated Malay } \\
& \text { States }\end{array}$ & $\begin{array}{ll}\text { Printing Presses } \\
\text { Ordinance } 1920 \\
\text { Printing Presses } \\
\text { Enactment } 1924\end{array}$ & $\begin{array}{l}\text { - Controlling the press as a } \\
\text { medium of internal racial } \\
\text { conflict among the } \\
\text { Chinese in Singapore and } \\
\text { Kuala Lumpur due to } \\
\text { differences in support for } \\
\text { the Chinese monarchy } \\
\text { since 1911. } \\
\text { - Against Japanese } \\
\text { propaganda }\end{array}$ \\
\hline Japanese Occupation & $\begin{array}{l}\text { - Under Supervision of the } \\
\text { Japanese military } \\
\text { administration } 1942\end{array}$ & $\begin{array}{l}\text { Japanese propaganda } \\
\text { machinery }\end{array}$ \\
\hline \multicolumn{3}{|c|}{ Malaysian Press in the Post-Independence Era } \\
\hline $\begin{array}{l}\text { Malaysian Government } \\
\text { Post- Independence } \\
\text { - } \quad \text { The incident of racial } \\
\text { unrest on } 13 \text { May } \\
1969 \\
\text { - Weeding Operation } \\
\text { - The political crisis and } \\
\text { racial unrest } 1969 \\
\text { - The political crisis } \\
\text { 1987 } \\
\text { - Economic Crisis } 1998\end{array}$ & $\begin{array}{ll}\text { - } & \text { Printing Press Act 1948, } \\
\text { - } & \text { Sedition Act } 1948 \\
\text { - } & \text { Defamation Act 1957, } \\
\text { - } & \text { Official Secrets Act } \\
& \text { 1972, } \\
\text { - } & \text { Internal Security Act } \\
& 1960 \\
\text { - } & \text { The Printing Presses and } \\
& \text { Publications Act } 1984\end{array}$ & $\begin{array}{l}\text { Controlling and Maintaining } \\
\text { state political stability and } \\
\text { prevent racial unrest due to } \\
\text { political and economic crisis }\end{array}$ \\
\hline
\end{tabular}

\section{CONCLUSION}

The reformation era was described as Indonesia's first martyr in press freedom in which there was no more censorship of the press - the press was now more open and critical. Thus, it was found that after going through the Dutch colonial rules, Sukarno's "Liberal and Guided Democracy", Suharto's "New Order" and post-Reformation", the dynamics of the 
press and the ruling regime in Indonesia were colored by issues of control versus press freedom. Apart from that, it was found that the newspapers that were established and cancelled were in line with the ideological rhythm and political policy orientation of each era of Indonesian rule.

On the contrary, in Malaysia, it was found that the press, from the time of the British occupation, Japanese rule to the time of independence, although there was a fierce conflict between the press and the government, the press still could not extricate itself from government control, and to this day remains the instrument of government to maintain the political power of the government. In another word, the press is not independent or is still under the control of the government. In short, the voice of the press is the voice of the government. Finally, different experiences as former Dutch and British colonies had an impact on the different objectives of the Indonesian and Malaysian press systems and policies.

\section{REFERENCES}

Adam, A. (1995). Sejarah awal pers dan kebangkitan kesadaran keindonesiaan. Jakarta: Hasta Mitra, Pustaka Utan Kayu Perwa kilan KITLV-Jakarta.

Andaya, B. W., \& Andaya, L. Y. (2016). A history of Malaysia. Macmillan International Higher Education.

Anom, E. (2008). Media dan politik kekuasaan: Suatu kajian pendekatan sistem. UIEU University Press.

Anom, E. (2009). Kebebasan pers: Perbandingan antara Malaysia dan Indonesia. Komunikologi: Jurnal Ilmiah Ilmu Komunikasi, 6(2).

Anom, E. (2013). Regulasi dan kebijakan media cetak di Indonesia masa zaman penjajah. Komunikologi: Jurnal Ilmiah Ilmu Komunikasi, 10(2).

Anom, E. (2015). Landasan kebebasan media di Indonesia. Komunikologi: Jurnal Ilmiah Ilmu Komunikasi, 12(2).

Anuar, K. (2000). Malaysian media and democracy. Media Asia. 27(4): 183-190

Arfin, A. (1988). Pers Indonesia. Ujung Pandang: LKII.

Atmadi, T. (1982). Development of the Indonesian press and its system. Jakarta: The Indonesian Press.

Badarudin,N.B.(2002). Dunia media moden. Pahang Darul Makmur: PTS Publication and Distributor Sdn.Bhd.

Hasim, M.S. (2005) Pers di Malaysia antara Kebebasan dengan Tanggung Jawab. Bangi. Penerbit Universiti Kebangsaan Malaysia.

Hasim, M.S., Sarji, A., \& Gunaratne, S.A. (2000). Handbook of the media in Asia. London: Sage Publication.

Hasim. M.S. (2004). Akhbar dan kuasa: Perkembangan sistem akhbar di Malaysia Sejak 1806.Kuala Lumpur:universiti Malaya.

Ho, H. L. (2009). Zaman pendudukan Jepun di tanah Melayu, 1941-1945: Penentangan orang Cina melalui Malayan People's Anti-Japanese Army (MPAJA). Malaysia Dari Segi Sejarah, Bil. 37, 2009, ms. 109-125.

Ibrahim, F. (2003). Pengaruh pengurusan akhbar ke atas bilik berita. In Samsudin A. Rahim, (Ed). Kumpulan esei: Isu-isu komunikasi (Pg 267-284). Bangi: Pusat Pengajian Media dan Komunikasi, Universiti Kebangsaan Malaysia.

Ibrahim, F. (2004). Language in the print media. In Asmah Hj Omar (Ed.)., Languages and Literature (Pg 132-133). Kuala Lumpur: Didier Millet. 
Idris, N. \& Gunaratne, S.A.( 2000) Indonesia. In Gunaratne, S.A (Ed). Hand book of media in Asia. London. Sage publication.

Ishak, M. (2012). Sistem penjajahan Jepang di Indonesia. Jurnal Inovasi, 9(01).

Kakiailatu, T. (2007). Media in Indonesia: Forum for political change and critical assessment. Asia Pacific Viewpoint, 48(1), 60-71.

Kusuma, A. (1981). Kebebasan pers dan arus informasi di Indonesia: Jakarta. Lembaga Studi Pembangunan.

Liow, J. C. (2004). The politics of Indonesia-Malaysia relations: One kin, two nations. Routledge.

Maters, M. (2003). Dari perintah halus ke tindakan keras: Pers zaman kolonial antara kebebasan dan pemberangusan, 1906-1942. Jakarta: Hasta Mitra, Pustaka Utan Kayu Perwakilan KITLV-Jakarta.

Mauliansyah, F. (2018). Studi perbandingan konflik pers Indonesia dan pers Malaysia dalam konteks nationality of press dan neighbor's press. SOURCE: Jurnal Ilmu Komunikasi, 3(1).

Moleong, L.J.(2007). Metodologi penelitian kualitatif. Edisi semak. Bandung: PT. Remaja Rosdakarya.

Nain, Z., \& Wang, L.K. (2004). Ownership, control and The Malaysian media. Who owns the media? Penang: Southbound, 34(4), 249-270.

Rachmiatie, A., Ravena, D., \& Yuniati, Y. (2020). The order of broadcasting regulation in regulating the implementation of broadcasting media (television and radio) in establishing local identity and culture. International Journal of Business \& Society, $21(\mathrm{~S} 1), 1-18$

Razak, A. (1986). The general characteristics of the Indonesian press. Media Asia, 13(4), 218-225.

Ricklefs, M. C. (2008). A history of modern Indonesia since c. 1200. Macmillan International Higher Education.

Samsudin, D., \& Nasution, K. (2021).Nilai Asas Etika Dalam Praktik Kode Etik Wartawan Indonesia: Perspektif Islam. In. Syam, H. M., Yuniati, U., Hardi, N. M., \& Tabroni, R.(Eds.). Book series jurnalisme kontemporer: Etika dan bisnis dalam jurnalisme.(Pg 106-206). Syiah Kuala University Press.

Sani, M. A. M. (2004). Media freedom in Malaysia. Journal of Contemporary Asia, 35(3), 341-367.

Sen, K., \& Hill, D. T. (2007). Media, culture and politics in Indonesia. Equinox Publishing.

Steele, J. (2011). Justice and journalism: Islam and journalistic values in Indonesia and Malaysia. Journalism, 12(5), 533-549.

Steele, J. (2013). "Trial by the press" an examination of journalism, ethics, and Islam in Indonesia and Malaysia. The International Journal of Press/Politics, 18(3), 342-359.

Sudibyo,S.(1999). Bung Karno: Analisis berita pers orde baru: Yogyakarta. BIGRAF Publishing.

Surjomiharjo, A. (2002). Berbagai segi perkembangan sejarah pers di Indonesia. Jakarta: Kompas Media Nusantara.

\footnotetext{
About the authors

Dafrizal Samsudin, Ph.D is a lecturer at Faculty of Communication Sciences, Universitas Islam Riau, Indonesia.
}

Faridah Ibrahim, Ph.D is a Professor of Journalism and Communication, Infrastructure University Kuala Lumpur, Malaysia. 